BEST TRUTH 
This page intentionally left blank 


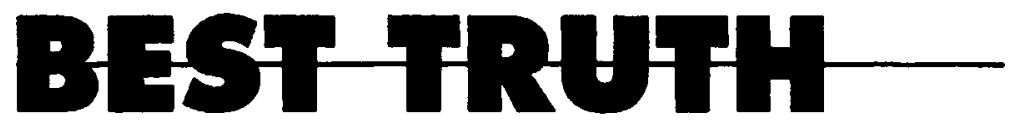

\section{INTELLIGENCE IN THE INFORMATION AGE}

\section{BRUCE D. BERKOWITZ AND ALLAN E. GOODMAN}


Copyright $\odot 2000$ by Yale University. All rights reserved. This book may not be reproduced, in whole or in part, including illustrations, in any form (beyond that copying permitted by Sections 107 and 108 of the U.S. Copyright Law and except by reviewers for the public press), without written permission from the publishers.

Designed by Mary Valencia.

Set in Bell Normal and Futura type.

Printed in the United States of America.

Library of Congress Cataloging-in-Publication Data

Berkowitz, Bruce D., 1956-

Best truth : intelligence in the information age / Bruce D. Berkowitz and Allan E. Goodman.

p. $\quad \mathrm{cm}$.

Includes bibliographical references.

ISBN 978-0-300-09397-1

1. Computer security. 2. Intelligence serviceUnited States. 1. Goodman, Allan E., 1944II. Title.

QA76.9.A25B48 2000

$005.8-\mathrm{dc} 2 \mathrm{I}$

$99-99990$

A catalogue record for this book is available from the British Library.

The paper in this book meets the guidelines for permanence and durability of the Committee on Production Guidelines for Book Longevity of the Council on Library Resources. 
To Judy, Mary Alice, and Rebecca;

Collette, Danielle, George, and A. J.;

and to the memory of William Colby

A time for silence

and a time for speaking ...

A time for war

and a time for peace.

-Ecclesiastes 3:1-8 
This page intentionally left blank 